九州大学学術情報リポジトリ

Kyushu University Institutional Repository

0xidative DNA damage in human esophageal cancer : clinicopathological analysis of 8hydroxydeoxyguanosine and its repair enzyme 久保，信英

ht tp://hdl. hand le. net/2324/1441070

出版情報 : 九州大学，2013，博士（医学），課程博士 バージョン：

権利関係：やむを得ない事由により本文ファイル非公開（2） 


\section{論文題名：Oxidative DNA damage in human esophageal cancer: clinicopathological analysis of 8-hydroxydeoxyguanosine and its repair enzyme}

（ヒト食道癌における酸化的 DNA 損傷 :

8-ヒドロキシデオキシグアノシンとその修復酵素に関する臨床病理学的検討）

区 分：甲

$$
\text { 論 文内容 の要旨 }
$$

外的要因や体内で発生した酸化ストレスはDNAに作用して発癌を促す。 8-hydroxydeoxyguanosine(8-OHdG)は酸化ストレスの指標で DNA の塩基配列にトランスバ ージョン変異を起こし発癌を誘発する。8-OHdG は 8-oxoG DNA glycosylase(OGG1)によっ て塩基除去修復される。そこで食道湂におり方酸化的 DNA 損傷と修復酵素の関係を明ら かにすることを目的として本研究を行った。食道癌手術症例 97 例の切除標本にて 8-OHdG と OGG1 の免疫組織化学染色をおこない各々の発現を評価した。（図 1 図 2) その結果食 道正常上皮（正常部）における 8-OHdG の発現レベルは喫煙指数が高いほよ゙高かった $(\mathrm{P}=0.0464) 。($ 表 1 ) 8-OHdG の発現は正常部に比較して癌部で高い( $\mathrm{P}=0.0061)$ 一方、OGG1 の発現は正常部に比較して癌部で低かった $(\mathrm{P}<0.0001)$ 。（図 3 ）正常上皮では 8-OHdG の

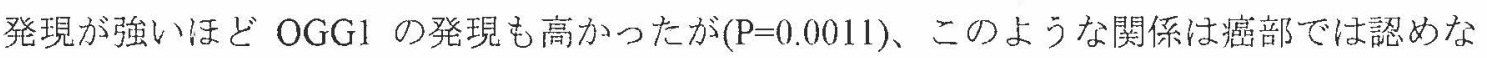
った。（図 4）癌の細胞質内の OGG1 が高発現の症例は低発現例より、深達度の深い症例 $(\mathrm{P}=0.0023) 、 リ ン ハ ゚$ 節転移陽性例 $(\mathrm{P}=0.00065) 、$ 、ステージの進んだ症例 $(\mathrm{P}=0.0019)$ の頻度が高 かった。（表 2）以上より、喫煙やDNA 修復機構の障害は酸化的 DNA 損傷をもたらし、 食道癌の発癌や進展に関係している可能性が示唆された。
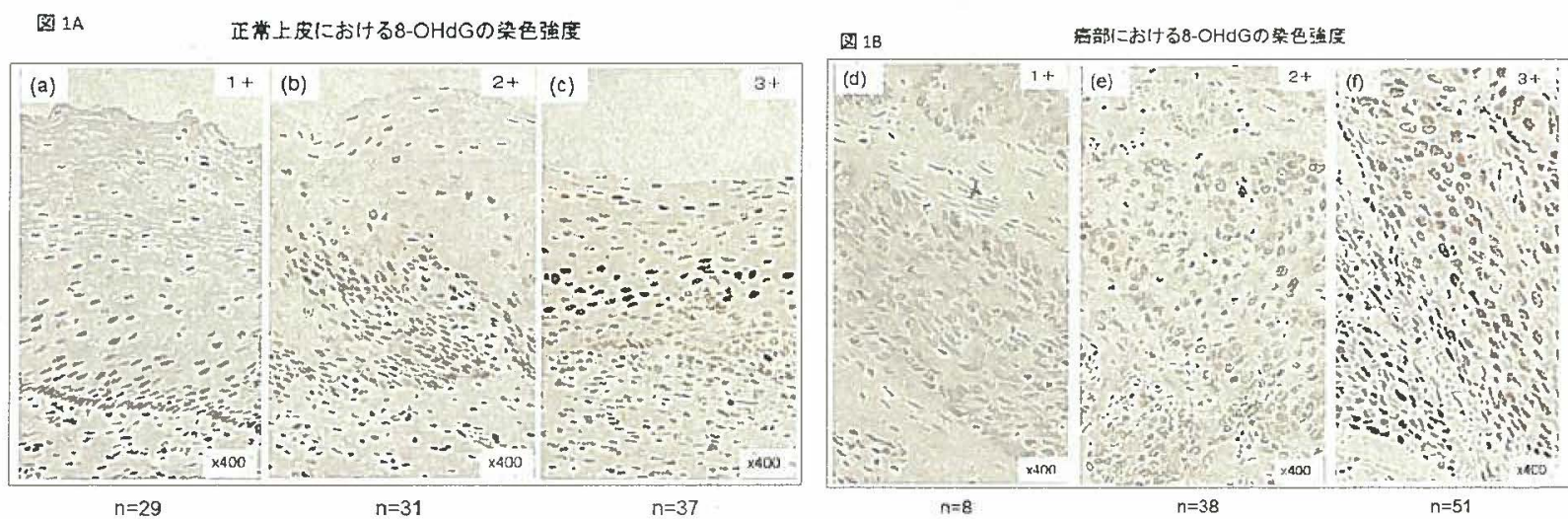
国

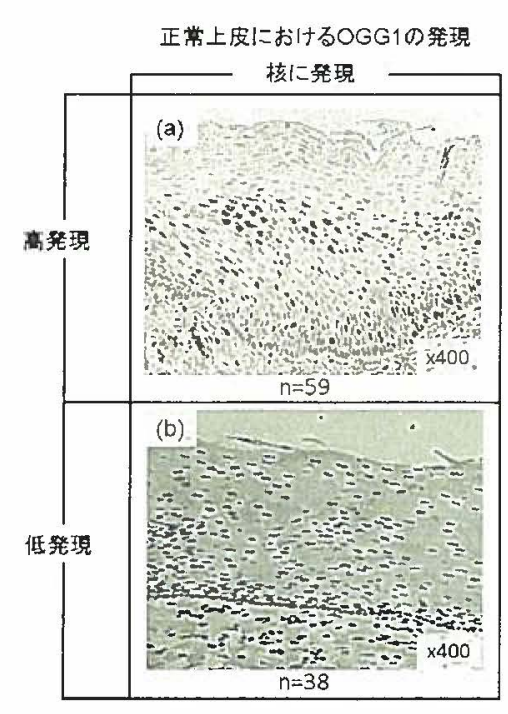

図 2B

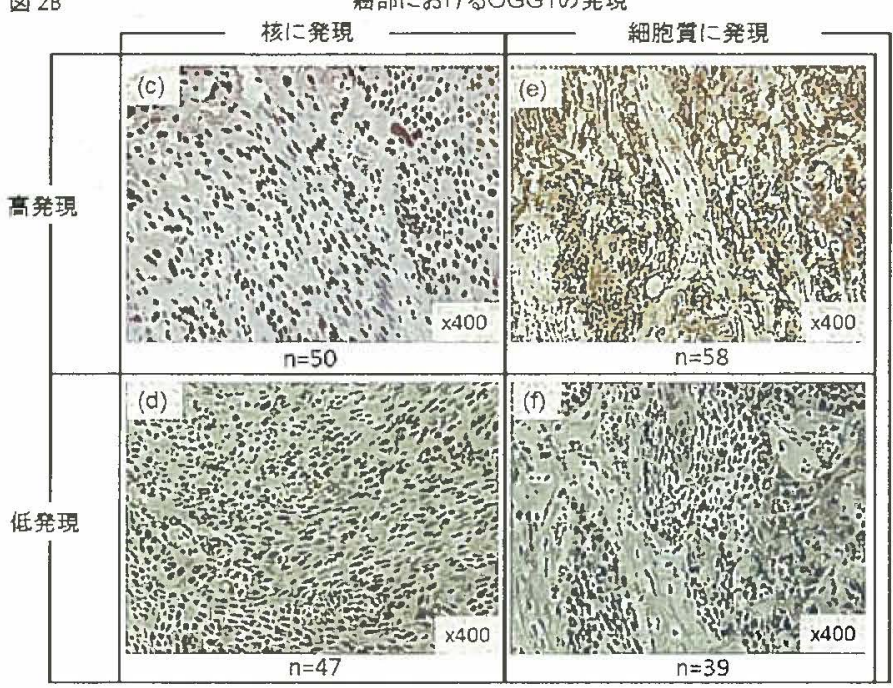

丧 1

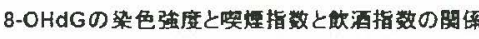

\begin{tabular}{|c|c|c|c|c|c|c|c|c|}
\hline \multirow[b]{2}{*}{ 因子- } & \multicolumn{3}{|c|}{ 正常上皮の8-OHdG } & \multirow[b]{2}{*}{ P-value: } & \multicolumn{3}{|c|}{ 满部の8-OHdG } & \multirow[b]{2}{*}{ P-value } \\
\hline & $\begin{array}{c}1+ \\
(n=29)\end{array}$ & $\begin{array}{c}2+ \\
\{n=31\}\end{array}$ & $\begin{array}{c}3+ \\
(n=37)\end{array}$ & & $\begin{array}{c}1+ \\
(n=8)\end{array}$ & $\begin{array}{c}2+ \\
\langle n=38\}\end{array}$ & $\begin{array}{c}3+ \\
(n=51)\end{array}$ & \\
\hline 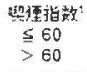 & $\begin{array}{r}26(90) \\
3(10)\end{array}$ & $\begin{array}{r}25,80] \\
6(20)\end{array}$ & $\begin{array}{l}24(65) \\
13(35)\end{array}$ & 00464 & $\begin{array}{l}7(88) \\
1(12)\end{array}$ & $\begin{array}{r}35(92) \\
3(8)\end{array}$ & $\begin{array}{l}33(65) \\
18(35)\end{array}$ & 00049 \\
\hline $\begin{array}{c}\text { 虾酎北数 }{ }^{2} \\
\fallingdotseq 80 \\
>80\end{array}$ & $\begin{array}{l}12(41) \\
17(59)\end{array}$ & $\begin{array}{l}17(55) \\
14(45)\end{array}$ & $\begin{array}{l}17(4 E) \\
20(54)\end{array}$ & 05547 & $\begin{array}{l}4(50) \\
4(50)\end{array}$ & $\begin{array}{l}21(55) \\
17(45)\end{array}$ & $\begin{array}{l}21141) \\
30(59)\end{array}$ & 0.4147 \\
\hline
\end{tabular}

- P-value is calculated with the $X=$ Test

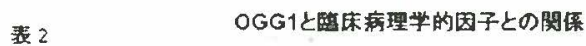

\begin{tabular}{|c|c|c|c|c|c|c|c|}
\hline & \multirow[b]{2}{*}{ 因子 } & \multicolumn{2}{|c|}{ 㹡ひOGG1 } & \multirow[b]{2}{*}{ P-yaluo" } & \multicolumn{2}{|c|}{ 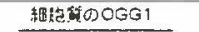 } & \multirow[b]{2}{*}{ F-valuo } \\
\hline & & $\begin{array}{l}\text { 低㱜现 } \\
(n=47)\end{array}$ & $\begin{array}{l}\text { 高染現 } \\
(n=50)\end{array}$ & & $\begin{array}{l}\text { 诋琵㻆 } \\
\{n=39\}\end{array}$ & $\begin{array}{l}\text { 高袹現 } \\
(n=58)\end{array}$ & \\
\hline 年省 & PP场 \pm SD & $65.4 \div 9.0$ & $616 \pm 95$ & 00638 & $650 \pm 7.2$ & $62.4 \pm 10.5$ & 01478 \\
\hline 路 & $\begin{array}{l}\text { 男性 } \\
\text { 交性 }\end{array}$ & $\begin{array}{c}44(94) \\
3(6)\end{array}$ & $\begin{array}{r}43(86) \\
7(14)\end{array}$ & 0.2110 & $\begin{array}{c}37(95) \\
2(5)\end{array}$ & $\begin{array}{r}50(86) \\
8(14)\end{array}$ & 0,1513 \\
\hline 組轱型 & $\begin{array}{l}\text { 恶分化 } \\
\text { 中分化 } \\
\text { 低分化 }\end{array}$ & $\begin{array}{r}7(15) \\
27(57) \\
13(28)\end{array}$ & $\begin{array}{l}12(24) \\
27(54) \\
17(22)\end{array}$ & 04988 & $\begin{array}{l}10(26) \\
18(46) \\
11(28)\end{array}$ & $\begin{array}{r}9(16) \\
36(62) \\
13(22)\end{array}$ & 02729 \\
\hline 泟金度 & $\begin{array}{l}\text { M. SH } \\
\text { MPLY }\end{array}$ & $\begin{array}{l}21(45) \\
26(55)\end{array}$ & $\begin{array}{l}28(56) \\
22(44)\end{array}$ & 02646 & $\begin{array}{l}27(69) \\
12(31)\end{array}$ & $\begin{array}{l}22(38) \\
36(62)\end{array}$ & 00023 \\
\hline 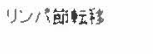 & 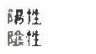 & $\begin{array}{l}23(49) \\
24(91)\end{array}$ & $\begin{array}{l}23(46) \\
27(54)\end{array}$ & 07722 & $\begin{array}{l}12(31) \\
27(69)\end{array}$ & $\begin{array}{l}34(59) \\
24(41)\end{array}$ & 00065 \\
\hline 進行䭅(ステーシ) & $\begin{array}{l}0 \\
1 \\
\text { II } \\
\text { III } \\
\text { IV }\end{array}$ & $\begin{array}{r}9(19) \\
7(15) \\
11(23) \\
15(32) \\
5(11)\end{array}$ & $\begin{array}{r}11(22) \\
9(18) \\
8(16) \\
15(30) \\
7(14)\end{array}$ & 08832 & $\begin{array}{c}14(35) \\
8(21) \\
9(23) \\
6(15) \\
2(5)\end{array}$ & $\begin{array}{r}6(10) \\
8(13) \\
10(17) \\
24(41) \\
10(17)\end{array}$ & 00019 \\
\hline
\end{tabular}

M.mucosa SH submueosa MP muscularis propria

'F value s caiculated with the Fisher s exact Test
图 3

(A) 8-OHdG の杂色強度

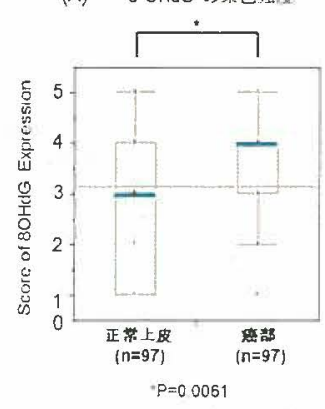

-P.salue s cakcuated with the Wicoxon signed-ranks Test

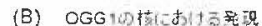

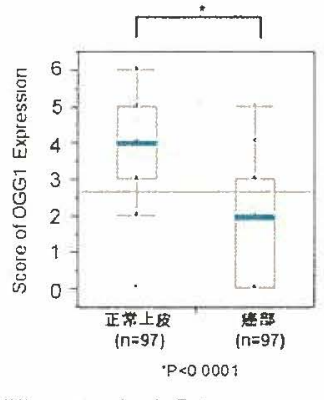

図 4

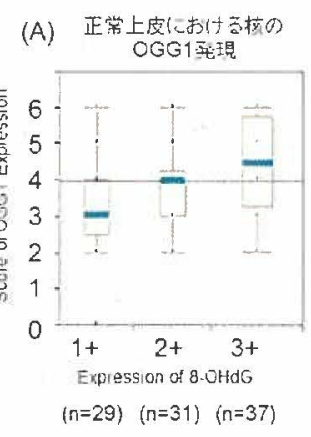

(B) 部に扩落の
OGG1発現

(C) 量部における稩胞前の

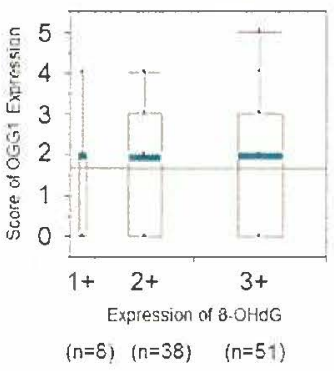

NS

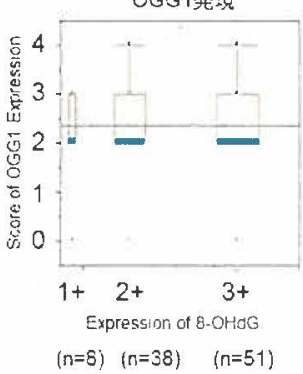

NS

-P-vaiue is calculated with the Jonckheere-Terpstra Test NS not significant 